\title{
Assessment of Road Rehabilitation in Ibadan, Nigeria
}

\author{
Adewale Olufunlola Yoade \\ Department of Urban and Regional Planning, College of Environmental Management and Design, Wesley University \\ Ondo, Nigeria.
}

\section{Samson Olaitan Olanrewaju.}

Department of Urban and Regional Planning, Faculty of Environmental Sciences, Kebbi State University of Science and Technology, Aliero, Nigeria.

\author{
Sesan Adeniyi Adeyemi. \\ Department of Urban and Regional Planning, Faculty of Environmental Sciences, University of Lagos, Nigeria.
}

Received: 2020-02-24 Accepted: $2020-07-19$

Keywords: Road; rehabilitation; government; gecay;

infrastructure

Correspondent email: yoadewale@yahoo.com

\begin{abstract}
The study examined road rehabilitation in Ibadan North East Local Government of Oyo State, Nigeria. The data used in this study was obtained from both primary and secondary sources. The primary data was obtained through a reconnaissance survey and administration of the questionnaire. The reconnaissance survey is appropriate to establish the nature of an environment, event or situation before making decisions. The population for this study consists of all the residents available in Ibadan north local government. Both descriptive and thematic content analysis was employed in the analysis. Findings showed that rehabilitation (3.33) is the most desirable facility in the study area. Construction, maintenance, traffic management capacity building and street naming followed with 3.01, 2.56, 2.42, 2.28 and 2.12, respectively. The study concluded that compensation is an important factor that can enhance sustainable urban renewal programme, and therefore resident whose building was affected are to be compensated so that they could secure a better place for living or for their transaction.
\end{abstract}

2020 by the authors. Licensee Indonesian Journal of Geography Indonesia.

This article is an open access article distributed under the terms and conditions of the Creative Common Attribution(CC BY NC) licensehttps://creativecommons.org/licenses/by-nc/4.0/.

\section{Introduction}

More than half of the world's population now lives in urban areas, and this is set to increase, mostly driven by growth in developing countries (UN-Habitat, 2011, 2014). Urbanization is the increase in the proportion of people living in towns and cities. It results from several factorsrural-urban migrations, the natural increase in urban population etc. Due to this fact, there will be lacks of housing; likewise, the facilities and infrastructures will not be adequate and enough for the population and with this there will be the needs for urban renewal to take place in environments like that. Urban renewal is a program of land redevelopment in areas of acceptable to high-density urban land use. Renewal has both successes and failures. Its modern incarnation began in the late $19^{\text {th }}$ century in developed counties and experienced a full phase in the late 1940s under the preface of renovation. The process had a main effect on various urban topography and has played an important role in the history and demographic of cities around the world (Adelekan, Olajide-Taiwo, Ayorinde, Ajayi, \& Babajide, 2014; Lawanson \& Agunbiade, 2017).

Urban renewal is often presented as a natural procedure through which the urban environment, viewed as a living entity, experience change. "As the year's pass, transformations take place, allowing the city to constantly rejuvenate itself in a natural and organic way". Also, urban renewal generally applies to inner-city areas, centrally located in historic districts, including non-residential as well as residential land uses (Grebler, 1964). According to Holcomb and Egunjobi (1987), stated that the first important urban renewal attempts in the United States were the American Park migration and the City Beautiful movement, both in the late nineteenth century, which appeared as responses to the environmental decadence brought about by the concurrence of urbanization and industrialization.

According to Greer (1965), the 1949 Renewal Program defined urban renewal as: "the diversified efforts by localities, with the support of the Federal Government, for the elimination and prevention of slums and blight, whether residential or non-residential and the withdrawal of the factors that produce slums and blighting situations."

The renewal program had three main components: slum prevention through neighbourhood conservation and housing code imposition; rehabilitation of structures and neighbourhoods; and clearance and redevelopment of 
structures and neighbourhoods (Gbadegesin \& Aluko, 2010). In developing countries, the process of urban renewal is still relatively new. Efforts are generally undiffused on solving the challenges of urban slums, where from 30 to $60 \%$ of the urban population inhabits and which are considered the accelerated stimulates portion of Third World cities (Hardoy \& Satterthwaite, 1981). Before the 1980s, the main approach to urban renewal in developing countries was in the form of squatter eliminate and replacement of the population to lowcost housing projects (Osuide, 2004).

Settlements were upgraded by amelioration the infrastructure and legalizing land tenure (Yoade, 2012). Today, upgrading remains the most sensible avenue to resolving the problems of informal settlements in Third World cities, although clearance is still commonly used. Rights that roadway investment offshoots new travel and thus fail to dismiss traffic obstruction, known as induced demand, have roads improvement in both the United States and Europe. This research problem past results by engaging a path model to causally sort out the links between freeway investments and traffic increases. Traffic increases are described in terms of both faster travel speeds and land- use moves that occur in response to adding freeway lanes (Agbola, Egunjobi \& Olatubara, 2007). While path prototype confirms the presence of induced travel in both short - and longer-run, projected elasticities are generally lower than those of earlier studies. This research also reveals important "induced growth" and "invoked confinement" effects -real estate development has veered to improved freeway corridors, and road investment have been shaped by traffic trends (Babanyara, Usman \& Selah, 2010). Fighting road project on the grounds of induced demand ought to be cautiously deliberated on. Energies might be focused on the highway sector and managing land-use change spawn by road confinement (Omole, 2000).

Limited issues in the urban transportation field have produced as much rationale and menace proposed road projects as claims of "induced demand" for decades; highway critics have charged that building new roads or expanding existing ones to dismiss traffic obstruction is an unsuccessful exercise. Developed roads simply spur additional travel or sidetrack trips from parallel routes, promptly returning a facility to its original overloaded condition. Traffic is supposed to behave more like a gas than a liquid. Onibokun (1985) stated that the challenge of diminishing urban neighbourhoods had been recognized in the United States since the mid-nineteenth century and over the years, main efforts have been made to counteract decompose and to rehabilitate cities throughout the country (Dimun. \& Omatsone, 2010). The criticisms of the Urban Renewal Program were many. Its application leads to the destruction of the homes and districts of the poor and minorities, and to the rearrangement of small businesses and the pulverize of inhabitable housing. Also, it directed too much investment to central business districts and not enough for positive actions in the districts and gave too little attention to social concerns (Jelilil, Adedibu, \& Ayinla, 2006).

Urban renewal involved rearrangements of business, and the pulverizing of structures, the relocation of people and the use of an eminent domain (government purchase of property for public purpose) as a legal tool to take private property for city emanated development project. These processes are carried out in rural areas, referred to as village renewal; however, it may not be accurately the same in practice. In specific cases, renewal may result in urban sprawl and less congestion when areas of cities freeways and expressway. Road expansion is the way by which the width of roads has been expanded as a result of traffic congestion. As travel and driving increase, it is always essential to consider whether, where, and how to expand roads. Policymakers must observe the land use and travel behaviour implications of the Blueprint in tandem with strategic road expansion (Teaford, 2000; Waque \& Hariji, 2005).

Increasing traffic congestion is an inevitable result of strong economic activity and life in contemporary metropolitan areas. Convincingly, large metropolitan regions lack the resources, citizen support, and ultimately the space to provide for uncongested automobile travel. Neither good transit nor extensive roadway capacity can eliminate obstruction challenges, although they can relieve certain corridors temporarily. About half of obstruction delay occurs in areas where demand has reached or exceeded capacity; the other half is due to incidents including weather, accidents, stalled vehicles and roadside perplexity. When a passageway becomes congested, all modes-transit; driving, bicycling and walking complement each other by serving specific types of trips, instead of competing (Mabogunje, 2002; Yoade, 2015).

According to the report, "Nigeria ranks tops compared with other countries in Sub- Saharan Africa in terms of the road network. The country has the largest road network in West Africa and the second largest, south of the Sahara with an estimated $200,000 \mathrm{~km}$ of the road network connecting villages to cities, the distant with the near and the inter-land with the urban market (Olojede et al., 2019)." The federal and state government roads that are paved are, in most cases not maintained. More often than not, these contribute to traffic congestion and delay in the city (Fadare and Wojuade, 2007a, 2007b; Fadare, Wojuola \& Durodola, 2007; Olojede et al., 2017a; Olojede Agbola \& Samuel, 2019). Therefore, this study examined road rehabilitation in Ibadan North East Local Government of Oyo State, Nigeria.

\section{The Methods}

Ibadan had been a capital city of the southwest region since 1939 when the Colony and Protectorate of Nigeria were trifurcated into three administrative units. Currently, the city is the capital of Oyo State. It is located approximately between latitude $7.37^{\circ}$ and $7.67^{\circ}$ North of the Equator and between $3.88^{\circ}$ and $4.17^{\circ}$ East of the Greenwich Meridian. Ibadan is about 145 kilometres from Lagos (the former Federal Capital of Nigeria) by road, and about 570 to 650 depending on the road plied kilometres northeast of Abuja (the current Federal Capital City) as the crow flies. Ibadan is directly connected to many towns in Nigeria and its rural hinterland by a system of roads, railways [moribund at present, though] and air routes.

Ibadan metropolis comprises eleven local government area five of them are in the main city (municipality) while the remaining six (6) are in its suburbs (also sometimes referred to as less city). The Ibadan metropolitan area can be divided into three distinct residential zones. This division can be linked to three historical periods, with their nature and characteristics determined by social, economic and physical patterns (Onibokun, 1985; Sanni \& Akinyemi, 
2009). They are the pre-colonial residential development (high-density/traditional), the colonial/pre-Independence residential development (intermediate/ medium-density) and the post-Independence residential development (lowdensity). Even the more recent classification by Onibokun \& Kumuyi (2004) of Ibadan metropolis into seven morphological regions can still be regrouped into these three residential zones. The zones are also obtained in such other traditional Yoruba cities as Ilorin (Akorede, 1975) and Ogbomoso (Afon, 2006).

Ibadan is an important socio-economic, administrative, educational and industrial centre (Olojede, 2015). The land use pattern compares with what obtains in other large cities in Nigeria. The general land use pattern of the Ibadan metropolitan area shows a clear distinction: purely nonagricultural use for Urban Ibadan, and agricultural use for Rural Ibadan. Residential land use is the most predominant among all land uses in the built-up part of Ibadan. The metropolitan area of the city has one of the highest population densities in the country, and the most densely settled areas remain the central and indigenous High of the city (Ayeni, 1994).

The first motorable road in Nigeria was constructed from Ibadan to Oyo in 1906, while the railway system which began in 1896 from Lagos to Kano in 1911 passed through the city. However, there is no internal rail system in the city. At present, there is no operational mass transit system in Ibadan. The implication of this is that there is a high prevalence of automobile use among residents who can afford automobiles. Less financially buoyant residents, especially commuters, take taxicabs, minibuses (danfos), and commercial motorcycles (okadas). According to Fadare \& Wojuade (2007a), 5.3\% of the roads in Ibadan are federal roads, $20.8 \%$ are state roads, while the remaining $73.9 \%$ are local government roads. Generally these roads are inadequate and in poor condition, especially the local government roads which are barely paved, and are in most cases not motorable during the rainy season.

The choice of Ibadan for this study is strategic for a number of reasons. Among other things, Ibadan has a metropolitan status which makes commuting indispensable. Meanwhile, as big as the city is its transport system is best described as being mono-modal, the only operating mode being the road. Besides, there is no sustainable public transit; as such, paratransit modes are predominant. In fact, in spite of its safety and security implications, the commercial motorcycle (popularly called Okada, named after Okada, a small town in Edo State of Nigeria where motorcycles were first used as a means of commercial transport in Nigeria in the 1980s) is quite pervasive, even along major roads and expressways. In fact, there are commuters who travel a distance of over 10 kilometres to work daily on commercial motorcycles. However, we look at it, commuting in Ibadan is an interesting phenomenon with its unique peculiarities. As such, conscientious caution should be the watchword when what obtains in the city in terms of commuting is being compared with what obtains elsewhere.

The data used in this study was obtained from both primary and secondary sources. The primary data was obtained through a reconnaissance survey and

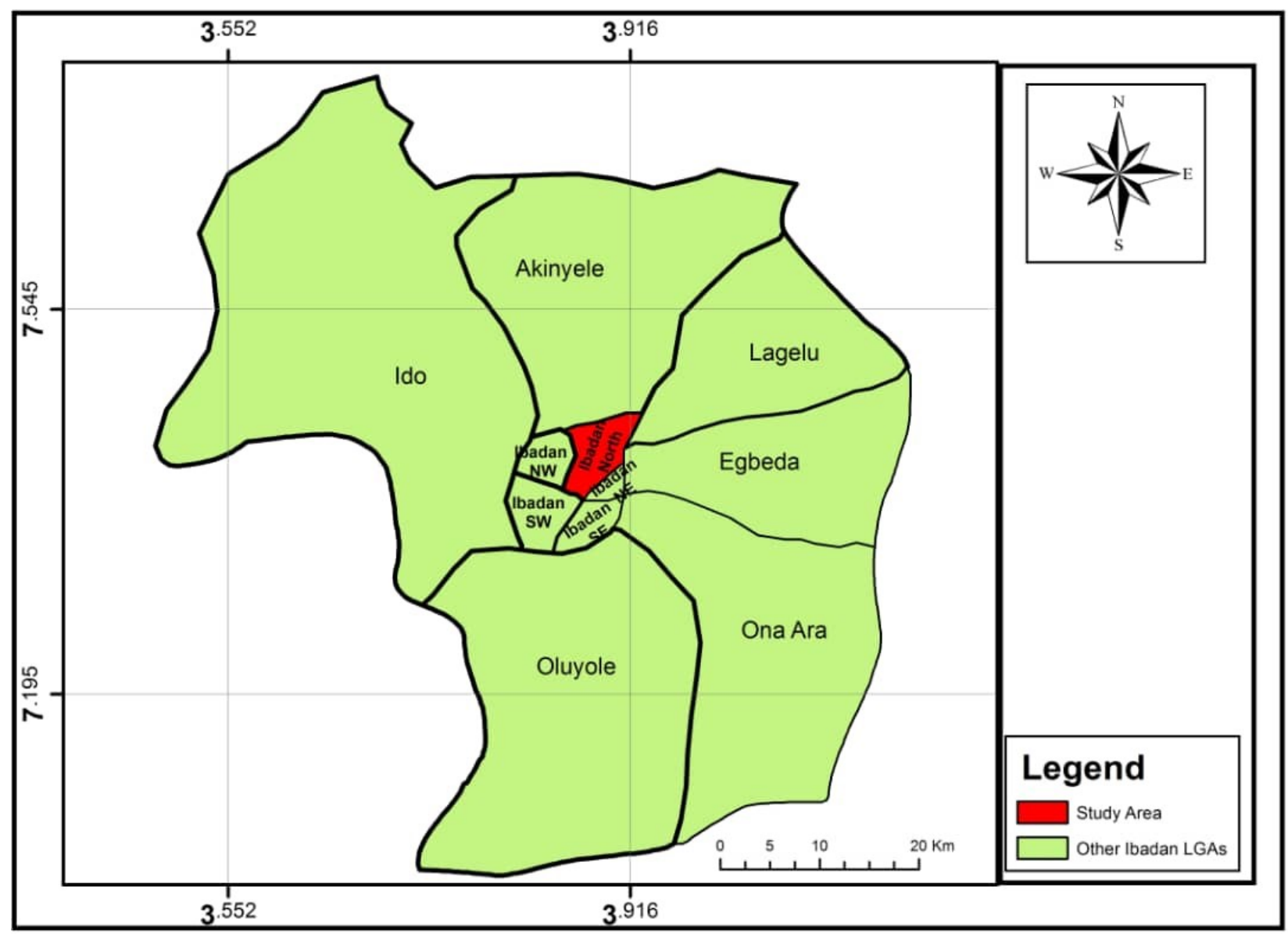

Figure 1.Map of Ibadan showing the study area (Source: Town Planning Authority, Ibadan, Nigeria) 
administration of the questionnaire. Once information from a primary source is evaluated, examined, or otherwise revised, it is a secondary source. These sources provide some comment on the original data and are therefore one step further removed from the source. The secondary sources that were consulted include journals, encyclopedia Britannica, textbooks and publication on road expansion and urban renewal, websites on the internet and information from Oyo state Ministry of Works. These were further categorized by stratification into the High, Medium and low-density residential areas. For the purpose of questionnaire administration for this study, in as much as the study area had been grouped into homogenous political wards (Daramola, 2015), one ward was randomly picked without replacement from each residential zone. In all, 15 wards were selected across all the three residential zones of the study area. Using systematic sampling technique, $5 \%$ of the buildings in the selected wards were sampled. The first building was randomly picked; subsequently, every 20th residential building in each ward was selected for the survey. From each of the sampled buildings, a household was randomly selected, and the household head was the respondent. Where the household head was not available, any available adult who was a commuter was surveyed. Therefore, a total number of 385 questionnaires were administered out of which 360 questionnaires were retrieved.

Data obtained from the study were analyzed using percentages and the Relative Importance Index (RII), which was employed to analyze, operationally, three different variables with a view to measuring either their relative importance or frequency. These variables are Relative Frequency of Causes of Bad Road Index (RFCBRI), Road Infrastructure Condition Index (RICI) and the Road Rehabilitation Assessment Index (RRAI) were used to analyze residents' assessment of the roads' condition and government's road rehabilitation performance, respectively. However, the underlying principle is essentially the same as what obtains in the more popular Relative Importance Index (RII). Consequently, the computation of RICI and RIDPI follows a process similar to the RII's. Literature abounds with many other similar applications. Corroborating with the studies of Afon (2000, 2006), Okoko, 2000, Sambasivan \& Soon (2007) \& Olojede et al. (2017a, 2017b, 2019). The respondents were guided through the rating of the two variables of interest following the principle of the Likert-type scale (Likert, 1961; Vagias, 2006). In each case, the scale was from 5 through 1 in descending order of significance (Excellent, Very Good, Good, Fair and Poor). The total weight value (TWV) for each variable was obtained through the summation of the product of the number of responses for each rating of the variable and the respective weight value. The mathematical expression for this is

$\mathrm{TWV}=\sum_{i=1}^{5} \mathrm{~N}_{\mathrm{i}} \mathrm{XW}_{\mathrm{i}}$

where $\mathrm{Ni}=$ the number of respondents rating the variable

$\mathrm{W} i=$ the average weight value assigned to the variable by the respondents.

RFCBRI for each bad road cause was computed by dividing the summation of the respondents' responses to each of the five ratings on the cause by the product of the highest weight attached to the value and the number of respondents. This is mathematically expressed as follows:

$\mathrm{RFCBRI}=\mathrm{TWV} / \Sigma={ }^{5}+\mathrm{Ni}^{i}$

1

The closer the TCCRFI of a cause is to 5, the stronger the respondents' rating of such a cause as of transit crime in Osogbo, and the farther it is from 5, the weaker the rating of respondents of such a factor as a cause of transit crime in the study area. Other variables were measured in a similar way, and are interpreted as accordingly.

Thus, the RICI was computed by dividing the summation of all the responses to each of the five ratings on it by the total number of respondents who rated the road infrastructure facility $(\mathrm{N})$.

The mathematical expression for this is

$\mathrm{RICI}=\mathrm{TWV} / \mathrm{N}$

The closer the RICI of a facility is to 5, the higher the residents' rating of it; the farther it is from 5, the weaker the rating of respondents of such a facility. The RRAI was also measured and computed the same way.

\section{Results And Discussion}

Socio-economic Information of the Respondents

The distribution of the respondents in this study area is contained in table 1 shows that $40.8 \%$ of the respondents were males, while $59.2 \%$ were females. The table below shows the age brackets of the respondents within the study area, with the highest been those between the age of 21-30 years of age having $58.9 \%$ while the lowest been those between 0-20 years of age having $9.4 \%$ (Table 1). The occupation is categorized into five, where the trading has a higher percentage of $51.9 \%$ and the artisan/professional with $3.1 \%$. The religion is characterized into two categories where the Islamic has a higher percentage of $68.1 \%$ and while Christianity has a lower percentage with $31.9 \%$. The tertiary Qualification has a higher percentage of $85.3 \%$ and while Primary Qualification has a lower percentage with 3.6\%. Ethnicity distribution of the respondents shows that majority of the respondents $(88.1 \%)$ are Yoruba while Hausa and Igbo accounted for $9.2 \%$ and $2.8 \%$ respectively. Similarly, only $21.4 \%$ of the respondents had lived in the study area for less than five years. In fact, $79.6 \%$ of them had spent over ten years in the city. Thus, they were familiar with the state of road infrastructure in the study area over the years. Further, vehicle ownership of the respondents was deemed very relevant to the study as the bulk of road infrastructure serves vehicles. People who have their own vehicles are likely to assess road infrastructure delivery performance differently from those who do not have any vehicle. Meanwhile, over $58 \%$ of the respondents indicated that they did not have any vehicle. This shows that the majority of the respondents were captive riders as private vehicle ownership in the town is rather low. However, we can safely consider their opinion relevant as there is no way they can do without using the road infrastructure for 
commuting and other economic activities. Generally, a cursory look at the socio-economic characteristics of the respondents is sufficient to establish it that they quite understood what the assessment was about (Table 1).

\section{Road infrastructure condition}

Prior to assessing the road infrastructure delivery performance in the study area, the respondents were asked to assess the state or condition of road infrastructure in the area with a focus on seven distinct elements. Table 3 gives a summary of their assessment.
According to Table 3, on the average, the condition of road infrastructure elements provided the government in the area is generally poor. Even with an average score of 2.32 out of 5, bridges/ culverts topped the assessment as the best road infrastructure element. Carriageways, streetlights, drainage, bus stops/laybys, traffic light, parking facilities and road signage ranked $2.25,2.21,2.13,2.11,1.83,1.76$ and 1.69, respectively. Further, a mean score of 1.9 was obtained for all the elements taken together. This shows that the respondents rated the state of road infrastructure in the city low.

Table 1.Socio-economic Characteristic of Respondents

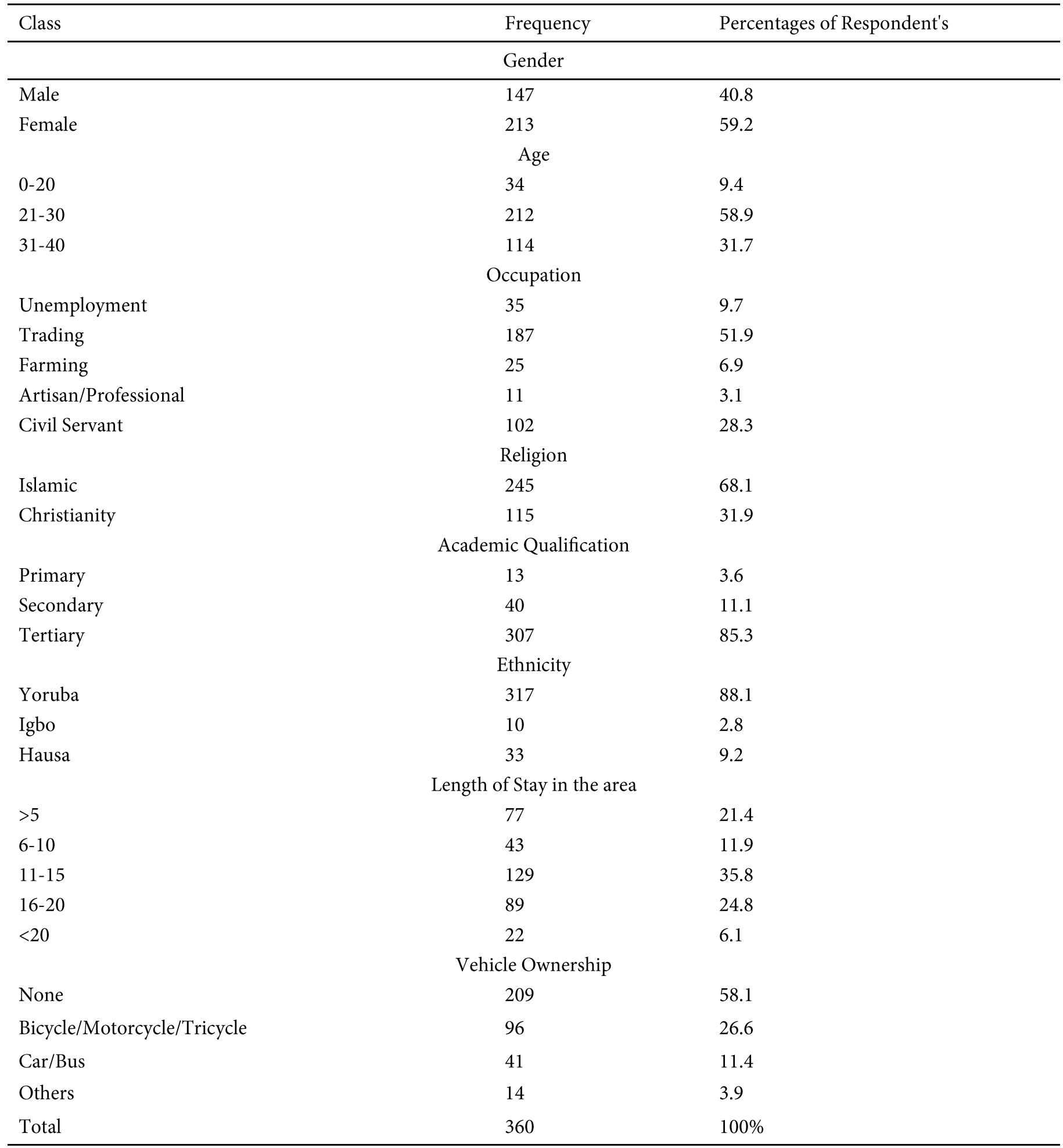


Table 2.Relative Frequency of Causes of bad road in Ibadan

\begin{tabular}{|c|c|c|c|c|}
\hline Causes & $\mathrm{N}$ & TWV & RFCBRI & Rank \\
\hline Lack of proper and timely maintenance & 341 & 1068 & 3.13 & 5 \\
\hline Unstable ground and poor drainage & 326 & 1123 & 3.44 & 3 \\
\hline Use of low quality materials in construction & 318 & 978 & 3.07 & 6 \\
\hline Poor workmanship and supervision of construction & 289 & 826 & 2.85 & 8 \\
\hline Flooding & 351 & 1009 & 2.87 & 7 \\
\hline Effect of weather condition & 293 & 973 & 3.32 & 4 \\
\hline Poor design and construction & 316 & 1250 & 3.95 & 1 \\
\hline Plying of heavy vehicles/traffic & 349 & 1340 & 3.83 & 2 \\
\hline
\end{tabular}

Table 3. Road infrastructure condition

\begin{tabular}{|c|c|c|c|c|c|c|c|}
\hline Variable & Excellent & Very good & Good & Fair & Poor & RICI & Rank \\
\hline Bridges/culverts & 36 & 19 & 45 & 187 & 73 & 2.32 & 1 \\
\hline Carriageways & 16 & 54 & 65 & 96 & 129 & 2.25 & 2 \\
\hline Streetlights & 5 & 34 & 83 & 149 & 89 & 2.21 & 3 \\
\hline Drainage & 9 & 44 & 68 & 106 & 133 & 2.13 & 4 \\
\hline Bus stops//laybys & 23 & 27 & 63 & 103 & 144 & 2.11 & 5 \\
\hline Traffic lights & 7 & 12 & 17 & 201 & 123 & 1.83 & 6 \\
\hline Parking facilities & 3 & 23 & 46 & 101 & 187 & 1.76 & 7 \\
\hline Road signage & 5 & 25 & 27 & 102 & 201 & 1.69 & 8 \\
\hline
\end{tabular}

Table 4.Road rehabilitation assessment

\begin{tabular}{llllllll}
\hline Variable & Excellent & Very good & Good & Fair & Poor & RRAI & Rank \\
\hline Rehabilitation & 104 & 86 & 36 & 95 & 39 & 3.33 & 1 \\
Construction & 41 & 65 & 138 & 89 & 27 & 3.01 & 2 \\
Maintenance & 16 & 29 & 174 & 86 & 45 & 2.56 & 3 \\
Traffic management & 31 & 35 & 72 & 139 & 83 & 2.42 & 4 \\
Capacity building & 22 & 48 & 68 & 96 & 126 & 2.28 & 5 \\
Street naming & 5 & 37 & 52 & 171 & 95 & 2.12 & 6 \\
\hline
\end{tabular}

Road rehabilitation assessment

Following the assessment of the state of road infrastructure elements, the respondents were asked to assess the road rehabilitation delivery performance in the area. Table 4 gives a summary of their assessment. Respondents scored government high in road rehabilitation (3.33), road construction (3.01) and road maintenance (2.56) in the study area. Traffic management, capacity building and street naming followed with 2.42, 2.28 and 2.12 , respectively.

\section{Discussion of findings}

This study has explored road rehabilitation in Ibadan, Nigeria. The findings of the study, as discussed in the foregoing section, are to a reasonable extent in consonance with what has been established by several previous studies in the literature of urban road maintenance and rehabilitation. In summary, the study found that several conventional rehabilitation/construction was executed in the study area as earlier found by Zeeman \& Lettinga (1999) and Abdulkareemn \& Adeoti (2005).

However, the study provides no empirical evidence to support the prevalence of some causes of bad road in Ibadan, Nigeria. Such bad road causes include poor design and construction, plying of heavy vehicles/traffic and unstable ground and poor drainage. The study also reveals the state or condition of road infrastructure in the city. According to the findings, the condition of road infrastructure elements provided by the government in the area is generally poor. This shows that the respondents rated the state of road infrastructure in the city low. These 
corroborate the findings of Enwerem, \& Ali (2016), Wazoh, Daku, \& Samuel (2016) and Saharuddin \& Ing (2019). It was also found by this study that respondents scored government high in road rehabilitation, road re-construction and road maintenance in the study area, as earlier established by Olojede, Agbola \& Samuel (2019).

More importantly, this study has given us important insights into understanding the road rehabilitation and maintenance issues in urban transportation in Ibadan. The implications of the findings of this study are many. They cut across physical planning, transport planning, and urban policing, among other institutional interests. Consequently, measures should be put in place by concerned stakeholders to engender a secure safe road environment in Ibadan, Nigeria.

In spite of the significant contribution made to the literature by this study, certain limitations are discernible. For example, though the study was able to assess the efficiency of road rehabilitation and maintenance in the study area, in terms of safety of road users, much was not reported in the assessment of security agencies' efficiency. Hopefully, this will be delved into by future studies.

\section{Conclusion}

For the purpose of this research, some actions were put in place so as to get correct data. The study took a critical view and the details of the urban renewal activities and hypothesized whether the work was mainly a road expansion activity or not. The extent of demolition and how the activities extended beyond the road areas were viewed to answer this poser.

From the research it was noted that the project is a good one because it makes life easier for road users both for the pedestrian workers and those with cars, it will ease traffic and reduce the accident rate. It was noted that the level of maintenance by the government agencies is low. Also is the fact that road users must be educated so as obey the road signs and advert dangers. This finding has identified some weaknesses, commonalities and gaps associated with various issues raised. The aim of planning is to promote a functional and aesthetic environment, where people enjoy maximum comfort and protection. Therefore the following recommendation will be helpful:

Relocation programs have to come in place for those whose buildings were affected especially the commercial centre because the urban renewal has a serious negative impact on their income, shopping complex can be built for them and with little payment and these should be done earlier before the program of the urban renewal activities commences so as to get affected people settled and continue with their business.

Compensation is also very important; a resident whose building was affected are to be compensated so that they could secure a better place for living or for their transaction. Also, educating the road users on how to obey road signs and the traffic light is very crucial because there are some road uses who might not understands what each sign means and what each light stands for or means. The government should, therefore, embark on educating the stakeholders. The department concern should regularly maintain the road, maintenances is another important factor to be considered after the road has been properly dualized and there is no proper maintenance from works department the road will soon return back to its normal formal state, i.e. it will start dilapidating.

\section{References}

Abdulkareem, Y. A \& Adeoti, K.A. (2005). "Road Maintenance and National Development" http://www.unilorin.edu.ng/ publications/abdulkareemya.htm

Adelekan, I., Olajide-Taiwo, L., Ayorinde, A., Ajayi, D. \& Babajide, S. (2014). Building Urban resilience: Assessing Urban and Peri-urban Agriculture in Ibadan, Nigeria. Padgham, J. and J. Jabbour (eds.)]. United Nations Environment Programme (UNEP), Nairobi, Kenya. DoI: http://www.start.org/upa/ ibadan.pdf

Afon, A.O. (2000). The use of residents' environmental quality indicator (EQI) data in the core residential housing

improvement. In: Akinbamijo OB, Famehinmi AS, Ogunsemi DR, et al. (eds) Effective Housing in the 21st Century Nigeria. Kanagawa: Global Environmental Strategies (IGES), pp. 115 -122 .

Afon, A. (2006). The use of residents' satisfaction index in selective rehabilitation of urban core residential areas in developing countries. International Review for Environmental Strategies 6(1): 137-152.

Agbola, T., Egunjobi, L. \& Olatubara, C.O. (2007). Housing Development and Management: A Book of Readings. Ibadan: Department of Urban and Regional Planning, University of Ibadan.

Akorede, V. (1975). Ilorin - A City in Urban Geography, An unpublished M.A. Thesis Submitted to the Department of Geography, University of Lagos, Nigeria

Ayeni, B. (1994). The metropolitan area of Ibadan: its growth and structure. Ibadan region, $72-84$

Babanyara,, Y.Y., Usman, H.A. \& Selah, F.A. (2010). An Overview of Urban Poverty and Environmental Problem in Nigeria. "Journal of Human Ecology" 31(2): pp. 135-145

Daramola O. P. (2015). Environmental Sanitation Practices in Residential Areas of Ibadan Metropolis, A PhD Thesis Submitted to Department of Urban and Regional Planning, Obafemi Awolowo University, Ile-Ife, Nigeria

Dimuna, O.K.. \& Omatsone, M.E.O. (2010): Regeneration in the Nigerian Urban Built Environment. Journal of Human Ecology, 29(2): pp. 141-149 (2010).

Egunjobi, L. (1987). Urban renewal: Issues, policies, strategies and planning. In: Onibokun, P. G.; Olokesusi, F.; Egunjobi, L. (eds.). Urban Renewal in Nigeria: 33- 43. Ibadan: NISER., Egunjobi, L. (1987). Urban renewal: Issues, policies, strategies and planning, Pp. 33- 43. In P. G. Onibokun, F. Olokesusi and LayiEgunjobi, Urban Renewal in Nigeria. (eds.). NISER, Ibadan

Enwerem, G.C. \& Ali, G.A. (2016): Economic Effects of Bad Roads on Vehicle Maintenance in Nigeria, International Journal of Scientific and Research Publications, Volume 6, Issue 6, June 2016761 ISSN 2250-3153 www.ijsrp.org

Fadare, S. O. \& Wojuade, C. A. (2007a). Study of Traffic Delay Situation in Ibadan, Nigeria. Ife Planning Journal 3(1), 1-15

Fadare, S. O. \& Wojuade, C. A. (2007b). Socioeconomic Effects of Traffic Delay in Ibadan Nigerian. Urban and Regional Planning Review 1(2), 100-107

Fadare, S. O., Wojuade, C. A. \& Durodola, G. A. (2007). Contribution of Commercial Vehicles to Traffic Congestion in High Area of Ibadan, Nigeria. LAUTECH Journal of Engineering and Technology 4(2), 63-74

Grebler, L. (1964). Urban Renewal in European Countries: Its Emergence and Potentials. Pennsylvania University Press, Pennsylvania

Greer, S. (1965). Urban Renewal and American Cities: The Dilemma of Democratic Intervention. Indianapolis: BobbsMerrill. 
Gbadegesin, J.T \& Aluko, B.T. (2010): The programme of Urban Renewal for Sustainable Urban Development in Nigeria: Issues and Challenges, Pakistan Journal of Social Science. Pp. 244-253.

Hardoy J.E. \& Satterthwaite, D. (1981). The Legal and Illegal City. In "Shelter Need and 284 Response: Housing, Land and Settlement Policies within Seventeen Third World Nations". Housing Today (a Journal of the Association of Housing Corporations of Nigeria (AHCN) 2002 1(6)

Jelilil, M.O.; Adedibu, A.A. \& Ayinla, A.K. (2006). Planning Implications of Housing Redevelopment in Density Areas of Ogbomoso, Nigeria: a pilot study. Journal of Human Ecology 2(3): 273- 277.

Lawanson, T. \& Agunbiade, M. (2017). Land governance and megacity projects in Lagos, Nigeria: the case of Lekki Free Trade Zone, Area Development and Policy. https:// doi.org/10.1080/23792949.2017.1399804

Likert R (1961): New Patterns of Management. New York: McGraw -Hill

Mabogunje, A L (2002). "Nigeria and the Good Urban Governance Campaign", Launching of the Global Campaign for Good Urban Governance in Nigeria, Federal Ministry of Work and Housing, Abuja, Nigeria

Okoko. (2000). Quantitative Techniques in Urban Analysis, Kraft Books Ibadan, Oyo State, Nigeria

Olojede, O. A. (2015). Trip-Chaining Behaviour of Households in Ibadan, Nigeria, An unpublished Ph.D. Thesis Submitted to the Department of Urban and Regional Planning, Obafemi Awolowo University, Ile-Ife, Nigeria

Olojede, O., Daramola, O. \& Olufemi, B. (2017a). Metropolitan transport safety and security: An African experience. Journal of Transportation Safety and Security 9(4): 383402.

Olojede, O., Yoade, A. \& Olufemi, B. (2017b). Determinants of walking as an active travel mode in a Nigerian city. Journal of Transport and Health 6:327-334.

Olojede, O.A., Agbola, S.B. \& Samuel, K..J. (2019). Residents' assessment of local government road infrastructure delivery in Ile-Ife, Nigeria, Local Economy 2019, Vol. 34(4) 346-363, sagepub.com/journals-permissions.

DOI: $10.1177 / 0269094219857044$

Omole, F.K. (2000). "Urban Renewal Process: Issues and strategies". Concept Books and Publication Company Nig. Ltd Ikeja, Lagos

Onibokun, A.G. (1985): The Future of Physical and Administration in Nigeria. National Workshop on Development Control and Planning Administration in Nigeria. Ibadan: NISER.

Onibokun, A. G., \& Kumuyi, A. J. (2004). Ibadan, Nigeria, The International Development Research Centre

Osuide, S.O. (2004). Strategies for Affordable Housing Stock
Delivery in Nigeria.18th Inaugural Lecture of Ambrose Alli University. Ekpoma. Benin City: Floreat Systems

Saharuddin, I.N.A. \& Ing, D.S. (2019). Factors Influencing Road Damage in Developing Countries, International Journal of Engineering Research And Management (IJERM), ISSN: 2349- 2058, Volume-06, Issue-02, February 2019

Sambasivan, M. \& Soon, Y.W. (2007). Causes and effects of delays in Malaysian construction industry. International Journal of Project Management 25: 517-526.

Sanni, L. \& Akinyemi, F.O. (2019). Determinants of Households' Residential Districts' Preferences within Metropolitan City of Ibadan, Nigeria, J Hum Ecol, 25(2): 137-141

Teaford, Jon. C. (2000). Urban Renewal and its Aftermath in United States: Urban Revitalization In America, 1940-1985. Baltimore, M.D. Johns Hopkins University Press. 2000: "Urban Renewal and its Aftermath". Housing Policy Debate. 11(2):146-152.

UN-Habitat (2011). Building urban safety through slum upgrading. Nairobi: UN-Habitat DoI:http://unhabitat.org/books/ building-urban-safety-through-slum-upgrading/

UN-Habitat (2014). Global Urban Indicators Database 2014.

Vagias, W.M. (2006). Likert-Type Scale Response Anchors. Clemson, SC: Clemson International Institute for Tourism and Research Development, Department of Parks, Recreation and Tourism Management, Clemson University. Available at: www.uc.edu/content/dam/uc/sas/docs/ Assessment/likert-type\%20response\%20anchors

Wazoh, H. N., Daku, S. S. \& Samuel, F.G. (2016). Investigative Study Of Possible Causes Of Failure Of A Section Of Road In Jos- Plateau, North - Central Nigeria, Journal of Multidisciplinary Engineering Science Studies (JMESS) ISSN: 2458-925X Vol. 2 Issue 11, November - 2016

Waque, S.F. \& Hariji, S.M. (2005): "Urban Renewal and Land Assembly. Where do we "Grow from Here"? Intentional Right of War Association, chap. 29.

Yoade, A.O. (2012). "A Study of Socio-Cultural Challenges to Urban Renewal in Ile-Ife, Nigeria." M.Sc. Thesis submitted to the Department of Urban and Regional Planning, Obafemi Awolowo University, Ile-Ife, Nigeria

Yoade, A.O. (2015). "Physical characteristics of core area of Ile-Ife, Nigeria." Analele Universităţii din Oradea - Seria GeografieXXV 2: 137-147. Available at: http:// istgeorelint.uoradea.ro/Reviste/Anale/anale.htm.2015.

Zeeman, G. \& Lettinga, G. (1999)." The Role of Anaerobic Digestion of Domestic sewage in Closing the Water and Nutrient Cycle at Community Level", W a t e r S c i e n c e and Technology, 39(5), 187-194. 